SHS Web of Conferences 2, 00003 (2012)

DOI: $10.1051 /$ shsconf $/ 20120200003$

(C) Owned by the authors, published by EDP Sciences, 2012

\title{
Financial evaluation of introduction of the electronic prescription for Latvian individual pharmacies
}

\author{
E. Ardava ${ }^{1}$, O. Onzevs ${ }^{2}$, I. Viksne ${ }^{2}$ and I. Namatevs ${ }^{2}$ \\ ${ }^{1}$ Rĭga Stradinš University, Latvia \\ ${ }^{2}$ School of Business Administration Turiba, Latvia
}

\begin{abstract}
Presently, there is a new paradigm for pharmacy practice defined and a concept of the "sevenstar pharmacist"given. The establishment of a new pharmacy system is looking for introduction and development of the electronic prescription. The aim of the study: to provide a sound research for individual pharmacies on the bases of discovering necessary financials for introduction of the electronic prescription. Results of the study: Financial aspects of the research have been evaluated by calculating payback time, ROI, NPV, and IRR. On the bases of financial calculations, the primary investment for initial costs for hardware and software has been estimated. Finally, express evaluation model for possible introduction of the electronic prescription at individual pharmacies without additional investment has been created.
\end{abstract}

Key words: individual pharmacies, electronic prescription, financial evaluation

With the advent of information technology pharmacy has been touched with a new paradigm, which is underpinned by Introductory Handbook (2006). This handbook is devoted to and emphasized pharmacy practice approach that should be carried out by doctors, patients, and pharmacies. Necessity of new paradigm is pointed out on a Foreword of Introductory Handbook and it sounds following:

"Pharmacists should move from behind the counter and start serving the public by providing care instead of pills only. There is no future in mere act of dispensing. That activity can and will be taken over by the internet, machines, and/or hardly trained technicians. The fact that pharmacists have an academic training and act as health care professionals puts a burden upon them to better serve the community than they currently do".

This new approach has named pharmaceutical care. On the basis of given definition International Pharmaceutical Federation (FIP) gives a key definition of pharmaceutical care.

"Pharmaceutical care is the responsible provision of drug therapy for the purpose of achieving definite outcomes that improve or maintain a patient's quality of life".

Pharmacists, being effective health care team members, may need skills and attitudes enabling them to assume many different functions. The concept of the "seven-star pharmacist" was introduced by World Health Organization (WHO) and taken up by FIP in 2000 in its general policy statement on Good Pharmacy Education Practice, which should cover such roles: caregiver, decision-maker, communicator, manager, life-long learner, teacher and leader.

According to Introductory Handbook, term researcher is added in it as an eight's function. With the naked eye there can be able to see that, in order to realize this conception or paradigm, it should be necessary to introduce a numerous innovations in practice, which should be entailed by Information and Communications Technologies (ICT). In addition, pharmacist in his everyday work ought to be engage in management, a system, which is complicated to manage.

This is an Open Access article distributed under the terms of the Creative Commons Attribution License 2.0, which permits unrestricted use, distribution, and reproduction in any medium, provided the original work is properly cited. 


\section{SHS Web of Conferences}

\section{Realization of the new paradigm in practice}

The new pharmacy paradigm subjects the pharmacy development; however, for each country that can be strongly different. Predominantly, the establishment of new pharmacy system is started with the development of the electronic prescription, which in many countries has already been established and successfully operated. According to technical specification of introduction of electronic prescription (Tehniskā specifikācija "Elektroniskās receptes informācijas sistçmas izstrāde un uzturēšana"), which is entailed with the development of e-prescription in Latvia, there are described some European countries existing experience in this field.

For instance, in the middle of ninetieths health data network Medcom was created in Denmark, through which 3 million e-post parcels every month including medical prescriptions for patients were sent. Since January 2007, electronically e-prescription network has been functioning. Prescriptions that are written out are further passed down to Denmark e-health portal and have been automatically registered on the each citizens ' medicine profile, which in its turn can be accessed by patient, treating doctor and pharmacy (which is authorized by patient by himself).

In Sweden, until the end of period of validity, all electronic prescriptions have to be kept on national level postbox called, Apoteket $\mathrm{AB}$, and only the writer out of the prescription, doctor and pharmacists can be able to reach them. Patient can receive necessary medicine to himself within the period to be stipulated and in any, no matter where it is located, Swedish pharmacy. During 2006, more than 20 million e-prescriptions were being written out in Sweden.

In Great Britain establishment of the e-prescription were being introduced in two stages - first stage, the paper format and electronic prescription flow has been mutually established, which later has been gradually replaced by electronically signed documents only. This is the way of establishment, which will have to take place in Latvia. Daily, 1.5 million prescriptions have been written out in Great Britain, and seven from ten are repeated prescriptions. Introduction of the electronic prescription can performed this process much quicker. By February 11, 2008, there was already written out 66,269,404 electronic prescriptions. At present, patients, if they wish by themselves, can get their prescription on paper format as well.

Since January 1, 2010, Estonia has introduced electronic prescription named e-prescription, which stipulated that the doctor no more issued a paper format prescription, but should send in it to data base, from where the pharmacy pharmacists can be able to take, execute, and hand out it to client.

The National Development Plan of Latvia for years 2007-2013, which is developed in 2006 and published by the Ministry of Regional Development and Local Government, is encouraged to develop ehealth solutions and use of information technologies, that's why it is necessary to research all processes that stands behind them. Regions' towns and regions small rural areas individual pharmacies have to inclusion into it. Introduction of expected e-health care system for Latvian pharmacies should have firmly sought for technical innovations. On the annual Baltic States pharmacists conference BaltPharm Forum 2009 the Estonian pharmacists once more have declared their statement:

"Pharmacies from the state did not receive any subsidies; thereby, approximately 30 pharmacies in country will be compromising after introduction of digital prescription".

Latvian pharmacies must go much more mature direction of development of the introduction of the electronic prescription; that's why it is necessary to provide forehanded and detailed analyze of the current situation, in order to predict further models of system introduction and action.

\section{Electronic prescriptions progress in Latvia}

On 2008, the State Agency of Medicines of Latvia tasked company AA Projekts, Ltd. for preparing and publishing a technical specification: Development and Maintenance of Information System for Electronic Prescription (Tehniskā specifikācija "Elektroniskās receptes informācijas sistēmas izstrāde un uzturēšana"). This document describes the current situation in circulation of the prescriptions, the 


\section{Int. Conf. SOCIETY. HEALTH. WELFARE; Congr. of Rehabilitation Doctors of Latvia}

main nature and purpose of the introduction of the electronic prescription, its advantages, and necessary changes in laws and regulations due to introduction of the electronic prescription.

As disadvantages of the paper format prescription are following: difficulty to trace prescription, hard to control it for the subject - are prescription medicine handed out only towards prescription or in cases when there is not paper format prescription at all. Sometimes, there is hard to recognize and read what information about certain medicine has been written on prescription, further it can create mistakes, when the medicine is handed out; thus, it turns to that patient must have to visit doctor once more to get right prescription. There is no assurance, is on the prescription written down right information about the patient? In addition, there is a quite large possibility of falsification of paper format prescription; and, the last, the time that should to be spent for compensating medicine processing is too much.

Advantages of the electronic medicine comparing with the paper format will be following, more transparent prescription movement; much quicker and more qualitative clients' service at pharmacies, less possibility for making a mistakes by pharmacist to be handed out medicine. Furthermore, information for research studies of the medicine usage by clients will be increased that will give more precise and quicker statistics to researchers and authorities.

Electronic prescription will be more convenient for patient use, as it will not be possible to lose it. Another reason will be concerning with data protection, it should be definitely increased. In addition, patient will have to get opportunity for receiving full information about medicine that has prescribed. If patient will arrive at stationary, the treating doctor would immediately get access to all information regarding medicine that had been before using by patient.

Doctor will, in his turn, get a summary about all applied medicine, which the patient has used. It will further decrease the medicine interaction risk. Doctor will control the patient's therapy schedule to be sure that patient has before purchased right medicine. Summarizing above mentioned there are find following:

- decrease the patients' inexpedient spending time by creating an electronic reservation information system of visits (e-appointment);

- increase the productivity of the doctors' everyday work improving access to information during the treatment process, and, ensuring the precise accounting and statistics about referrals creating e-referral information system;

- increase society's and patients information about existing health problems and motivation, succeed for one's health, as well as creating one environment for patient and doctors. Personalize information and electronic services through created health portal for society will have been accessing;

- introducing e-health solutions will have been ensuring information security and personal data protection at health care institutions.

"AA Projekts", Ltd. from the technical point of view has met with difficulties, which are related to introduction of electronic prescription in practice. The most important are: the problem concerning data protection; although, if the electronic system is rightly projected it would be more secure comparing existing paper format prescription. It would be possible to touch with illegal utilization risk of the system; for instance, the employee of the registration office writes out prescription utilizing doctor's identification. Technical supply with computer and internet connection for all doctors' practice is necessary. One very important question is that for introduction of electronic prescription the outside funding is necessary. It is not clear at this moment, which will be ready for paying establishing doctors' practices and pharmacies information systems, which will be paying for necessary software. There do also exist some technical problems - as stability of the network and absence of infrastructure at regions' small rural area.

\section{Research object and tasks}

On April 30, 2010, the number of pharmacies are decreased reaching 845: among them pharmacist as one of the owners of the pharmacy 124 pharmacies; pharmacist as an owner of the pharmacy 87 


\section{SHS Web of Conferences}

pharmacies; pharmacists, assistants of pharmacist, persons with other education or collective body of pharmacy 216 pharmacies. There are 427 individual pharmacies, which mainly are located in region towns and region small rural areas. These pharmacies are the object of the research, which means, approximately a one half from the total number of all Latvian pharmacies. The rest 418 pharmacies belong to the pharmaceutical chains, which are mainly located in 9 cities - Riga, Jurmala, Jekabpils, Jelgava, Daugavpils, Liepaja, Ventspils, Valmiera un Rezekne, as well as, in large regional cities.

Our task was to size up how Latvian regional towns' and regional small rural areas individual pharmacies realizes current provision of law at pharmaceutical care, how the owners of the pharmacies look forward on introduction of IT for expected electronic prescription introduction. Comparing to other pharmacies individual pharmacies mainly are located at region small rural areas where the density of the population is low, but the serving area broad.

Problems will rise for these pharmacies, if small pharmacies will have to finance introduction of pharmacy information system by themselves. Initially, together with electronic prescription paper format prescription is anticipated. For long term both electronic and paper format might be economically unprofitable for government. Thus, small pharmacies should be ready to update their operations. Having unable to do that, it can take negative impact on an availability of the medicine and health care at region areas. Due to transport problems, not all countryside population will be able to go to the nearest regional city for necessary medicine, So, two main research tasks have been risen on issue:

1. Performing questionnaire survey, to define pharmacies attitude and readiness towards pharmaceutical care.

2. Counting all primary costs, consist with introduction of electronic prescription and possible consequences.

\section{Costs express analysis for ICT systems introduction}

One of the key points of introduction of ICT system for Latvian individual pharmacies is capital budgeting (Roultsone, Phillips, 2008). From the business point of view, the introduction of the new information system ought to have got an additional profit or at least cost decrease for individual pharmacies. Operations around individual pharmacies we cannot evaluate from the business perspective. Calculation on capital budgeting is based on project management and we assumed that ICT system introduction is a project (Guide to Cost-benefit Analysis of investment projects).

Once the potential capital budgeting has been identified its evaluation is based on the following methods. First method is to calculate net present value (NPV), which relies on discounted cash flow (DCF) techniques. To implement this approach it should be proceed as follows. (1) Find the present value of each cash flow, including both inflows and outflows, discounted at the ICT systems cost. (2) Sum these discounted cash flows and this sum is defined as the ICT systems NPV. (3) If NPV is positive, ICT system should be accepted, while, if the NPV is negative, it should be rejected.

The equation for the NPV is as follows:

$$
N P V=\sum_{t=0}^{n} \frac{C F_{t}}{(1+r)^{t}}
$$

where, $\mathrm{CF}_{\mathrm{t}}$ - is the expected net cash flow at period $\mathrm{t}, \mathrm{Ls}$

$$
r \text { - is the ICT system's cost of capital or discount }
$$

coefficient

$$
\mathrm{n} \text { - is its life (in years) }
$$

Net cash flow at period $t$ is as follows:

$$
C F_{t}=N I_{t}+D e p_{t}
$$

where, $\mathrm{NI}_{\mathrm{t}}$ - is net profit at period $\mathrm{t}$, Ls 
Int. Conf. SOCIETY. HEALTH. WELFARE; Congr. of Rehabilitation Doctors of Latvia

Table 1. Necessary current profile, grouped, as foregone incomes, after systems introduction.

\begin{tabular}{|c|c|c|c|}
\hline \multirow{2}{*}{$\begin{array}{c}\text { Primary } \\
\text { investment, Ls }\end{array}$} & \multicolumn{4}{|c|}{ Current profit, in Ls, if foregone income after system's introduction (NPV $>0)$} \\
\cline { 2 - 4 } & $\geq 50 \%<100 \%$ & $\geq 20 \%<<0 \%$ & $<20 \%$ \\
\hline $\mathbf{1 5 0 0}$ & $>\mathbf{6 5 0}$ & $>1300$ & $>\mathbf{3 8 5 0}$ \\
\hline $\mathbf{2 0 0 0}$ & $>\mathbf{7 0 0}$ & $>1450$ & $>\mathbf{4 2 5 0}$ \\
\hline $\mathbf{2 5 0 0}$ & $>\mathbf{7 5 0}$ & $>1550$ & $>\mathbf{4 7 0 0}$ \\
\hline $\mathbf{3 0 0 0}$ & $>\mathbf{8 0 0}$ & $>1700$ & $>\mathbf{5 0 5 0}$ \\
\hline
\end{tabular}

Net profit calculation which is based on gradually table calculation method which can be transformed in one common equation where corporate income tax is to consider as a function:

$$
N I_{t}=N O I_{t}-\operatorname{Dep}_{t}-I_{t}-T\left(N O I_{t} ; \operatorname{Dep}_{t} ; I_{t}\right)
$$

where, $\mathrm{NI}_{\mathrm{t}}-$ net profit at period $\mathrm{t}$, Ls

$\mathrm{NOI}_{\mathrm{t}}-$ operating profit including depreciation at period, $\mathrm{t}, \mathrm{Ls}$

Dep $_{t}$ - depreciation at period $t, \mathrm{Ls}$

$\mathrm{I}_{\mathrm{t}}-$ interest payments at period $\mathrm{t}, \mathrm{Ls}$

$\mathrm{T}\left(\mathrm{NOI}_{\mathrm{t}} ;\right.$ Dep $\left._{\mathrm{t}} ; \mathrm{I}_{\mathrm{t}}\right)$ - corporate income tax at period $\mathrm{t}$

as a function of operating profit, depreciation at period $t$, and interest payment at period $t$ in Ls. Second method is to calculate the ICT system payback time. Third, the return on investment (ROI) and, fourth, internal rate of return (IRR).

Primary investment that anticipates initial costs for hardware and software has been estimated in range from 1500 to $3000 \mathrm{Ls}$. Calculations is based on the smallest monthly maintenance costs $35 \mathrm{Ls}$ and coefficient of discount 0.05 .

Original calculations show that there are not expected not substantial costs decreases nor revenue increases. In fact, the introduction of the ICT system will not be able to create an additional cash flow for individual pharmacies. There are restrictions in legislation in Latvia on issuing the licenses for pharmacies operations' depending from the number of local inhabitants. That is the answer why in rural areas unlike large cities there is only one pharmacy with permanent number of its clients. It is potentially impossible substantially increase a number of its clients. As a result, individual pharmacies are not a unit of business in its normal sense. Thus, the public authorities ' decisions in case of introduction of ICT system are important for them.

Calculating capital budgeting there is evaluated individual pharmacies cash flow at ten-year period starting from introduction of the ICT system from ground. It is based on and depends on current annual profit (profit before introduction of the ICT system).

If current annual profit does not cover 50\% from primary investment then there is anticipated to take credit from bank at 5-year period with an interest rate from five to $10 \%$. Calculation shown on Table 1 illustrates necessary current profit derived from foregone income for three different groups (for all groups NPV>0). (1) Foregone income is less than $20 \%$ from total annual profit. Individual pharmacies belonging to this group, whatever is the primary investment, will not touch with problems of introduction of the ICT system. (2) Foregone income is more than $20 \%$, but less the $50 \%$. Individual pharmacies belonging to this group are under discussion. (3) Foregone income is between 50\% and $100 \%$ from annual profit. Individual pharmacies belonging to this group are not able to introduce ICT system and e-prescription, also.

On the basis of this calculations, there can be predicted that the introduction of the system is not possible at all, if current profit is less than 650 Ls. Moreover, financially weak individual pharmacies have currently incomplete infrastructure and introduction of the system charges higher investments for them. That means, after 10 year period the new system will create losses and will go bankrupt those pharmacies whose current profit does not today reach 800 Ls. Pharmacies with annual profit from 


\section{SHS Web of Conferences}

Table 2. Number of pharmacies and estimated profit depending from pharmacies turnover.

\begin{tabular}{|c|c|c|c|}
\hline $\mathrm{Nr}$ & $\begin{array}{c}\text { Turnover of pharmacy and } \\
\text { percentage from total number } \\
\text { of pharmacies }\end{array}$ & $\begin{array}{c}\text { Number of } \\
\text { pharmacies }\end{array}$ & Estimated profit \\
\hline 1. & to $20000(8 \%)$ & 34 & Not \\
\hline 2. & $20000-50000(28 \%)$ & 120 & Not \\
\hline 3. & $50000-100000(32 \%)$ & 137 & to 3000 \\
\hline 4. & $100000-200000(16 \%)$ & 68 & $3000-5000$ \\
\hline 5. & $200000-500000(16 \%)$ & 68 & $5000-10000$ \\
\hline
\end{tabular}

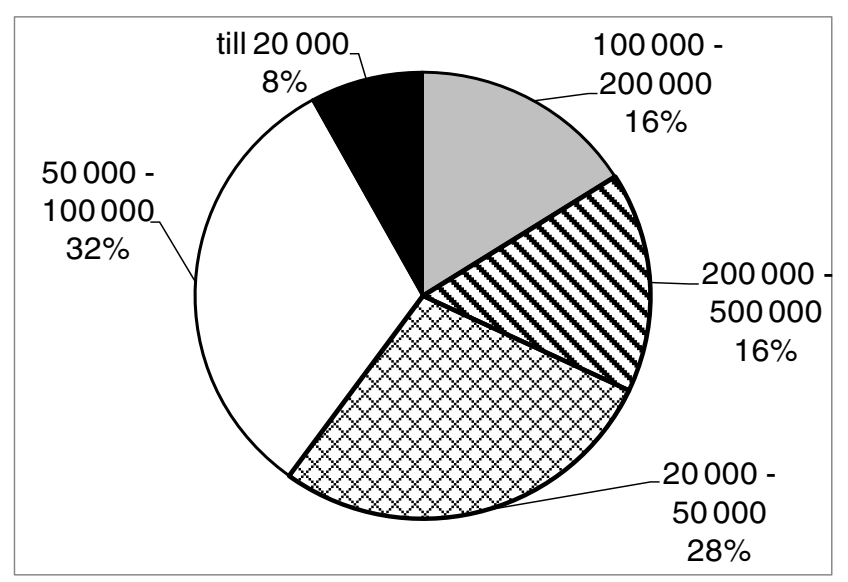

Figure 1. Provincial towns' and countryside pharmacies turnover in lats.

$1300 \mathrm{Ls}$ to $1700 \mathrm{Ls}$ are also threatened and introduction of the new system is under consideration. In general, this system could be introduced at pharmacies, whose current profit reaches beyond 3850 Ls. Capital budgeting research has been established a fact that taking a credit from bank marginally influence the data shown on Table 2 . Because, in relation to primary investment there are comparatively high operating costs, which annually are 420 Ls or $14 \%$ to $28 \%$ of current investment.

Figure 1 shows sample of 36 provincial towns' and countryside pharmacies turnover in Latvian lats from the population of 427 pharmacies.

In order to perform an express analysis the data is proportionally taken based on the pharmacies annual turnover, see Figure 1. Taking into account express analysis and expert estimate, the potential profit depending from the pharmacies turnover has been calculated. This of course depends on different additional collateral factors: space rent, salary etc. As a result, there has a first approximation of estimated profit depending from pharmacy turnover see Table 2.

\section{Conclusions}

Problems of introduction of electronic prescription will be risen for two thirds of all Latvian individual pharmacies. There can be several solutions for this case: joint venture for introduction of electronic prescription, government support, attraction of EU structural funds, or other solutions.

From the financial point of view introduction of the system is not possible for $36 \%(8 \%+28 \%)$ of total number of pharmacies. Moreover, financially weak pharmacies have incomplete infrastructure and introduction of the system charges higher investments to them. These pharmacies cannot increase their situation by simply borrowing money from bank, because in relation to primary investment there 
Int. Conf. SOCIETY. HEALTH. WELFARE; Congr. of Rehabilitation Doctors of Latvia

exist comparatively high operating costs, which annually constitute 14 to $28 \%$ of primary investment. Planning system would be successfully introduced by pharmacies whose profit reaches 3850 Ls. Problems will be risen for $34 \%$ all registered pharmacies or $68 \%$ individual registered pharmacies in Latvia.

It is quite clear that the biggest part of individual pharmacies will not separately be ready to introduce necessary innovations in their practice. The given research of pharmacies has also shown that the biggest part of pharmacies have only a weak sense on above mentioned innovations and necessity of establishment of the system. After study of the problem, there would be several solutions: joint venture of pharmacies, government support, attraction of EU structural funds, etc.

\section{References}

[1] Handbook. (2006) Developing Pharmacy Practice. A Focus on Patient Care. (Karin Wiedenmayer, Rob S. Summers, Clare A. Mackle, Andries G. S. Gous, Marthe Everard); World Health Organization (Department of Medicines Policy and Standards, Geneva, Switzerland), In collaboration with International Pharmaceutical Federation (The Hague, The Netherlands).

[2] Tehniskā specifikācija "Elektroniskās receptes informācijas sistēmas izstrāde un uzturēšana”. Rīga, ZVA, 2008. http://www.vm.gov.lv

[3] Roultsone, B. D., Phillips, J.J. (2008) ROI for Technology. Measuring and Delivering Value. Elsevier, p. 343.

[4] Guide to Cost-benefit Analysis of investment projects. Final Report. (2008). European Commission, p. 255.

[5] Farmācijas likums. (1997) http://www. likumi.lv 